\title{
EL CATOLICISMO CHILENO Y LA GUERRA CIVIL ESPAÑOLA, 1936-1939. NOTAS Y MATERIALES PARA SU ESTUDIO
}

\section{INTRODUCCIÓN}

Ningún acontecimiento universal durante la década de 1930 representó para la opinión pública hispanoamericana la antítesis de los paradigmas totalizadores de la sociedad, como la guerra civil española. El conflicto peninsular polarizó a la opinión pública, los intelectuales y las instituciones en el continente americano. En este marco cabe descubrir otra dimensión en el impacto de la conflagración hispana. Concuerda con la revitalización del catolicismo - por la divulgación del neotomismo y la fundación de la Acción Católica-y por el intento de formular un esquema socio-político que supere el capitalismo y las formas presupuestadas por el marxismo. Esto condujo a vastos sectores del catolicismo a visualizar como modelo político el corporativismo. La encíclica Quadragesimo Amo, de 1931, daba cierto aliento a tal derrotero.

La guerra civil en suelo español puso en el tapete una convergencia del catolicismo con el modelo corporativista - que se manifestó en el bando de Franco- y fueron elementos que se discutieron en el interior de la iglesia chilena. Paralelo a ese debate, discurrieron varios temas íntimamente relacionados con el conflicto hispánico, donde no faltaron el replanteamiento de la cultura nacional, la dimensión de lo religioso en el terreno político, o el análisis de los paralelos de la situación socio-económica chilena con la española y francesa a la sombra del surgimiento de las plataformas frentepopulistas en los tres países.

En el caso particular de Chile hemos optado por hablar más de catolicismo en general que de Iglesia Católica, puesto que el 
primer concepto engloba las actuaciones del episcopado, lass publicaciones católicas y los laicos en la Iglesia, etc.

La conflagración española repercutió en América Latina en diversos niveles. Y por esa razón fue percibida y valorada de distinta forma. La guerra civil denotó una visión de la historia -y también una cosmovisión- además de simbolizar ideales políticos antagónicos universales y contemporáneos, por parte de los respectivos gobiernos - republicano y nacional- en la España de 19361939. Lo histórico, en cuanto a interpretación del pasado común colonial y la herencia española en Hispanoamérica, fue abordado de modos diferentes. Los ideólogos y publicistas del bando nacional proyectaron una visión de grandeza imperial y rescate de la España monárquica y católica, cuyos modelos estaban en los reyes de la Casa de Austria. A esta visión, los republicanos y la izquierda, retomaron la crítica liberal y heterodoxa de su historiografía, cuestionando los elementos históricos tradicionales (vr. gr. el catolicismo, la monarquía de los Hasburgos, etc.), y determinados aspectos medulares del sistema colonial implantado en América. Este aspecto se percibió estrechamente ligado al contexto político americano. Puede decirse que el conflicto se vivió como algo nuestro, que importaba seriamente a Hispanoamérica. Esto abrió otra perspectiva para la guerra civil española, pues se enlazó como otra etạ̣a en la historia de las relaciones entre Hispanoamérica y España. Considerado lo expuesto, no fue extraño que abordados en su nivel político-religioso los sucesos españoles encontraran la adhesión natural de los gobiernos conservadores - y la Iglesia en generalpor el bando nacionalista, aunque no intervinieran en la guerra. ${ }^{2}$ Así ocurrió con el «Estado Novo» de Getulio Vargas en Brasil, siguiendo la inspiración corporativista del Portugal de Oliveira

1 Octavio Paz en su ensayo «México y los poetas del exilio español» (1979) anota: «Las dos interpretaciones ---la universalista y la nacionalista-- no agotan el tema. Hay todavía otra perspectiva: la guerra civil española y la emigración republicana son un capitulo de otra historia igualmente tormentosa: la de las relaciones entre México y España. A su vez, esa relación es parte de otra historia más vasta: América y España». Conf. Octavio Paz: Hombres en su siglo y otros ensayos. Barcelona, 1984, pág. 48 .

2 Jackson, Gabriel: Breve historia de la guerra civil de España. Paris. 1974, pág. 67. 
Salazar. Por el contrario, el gobierno de Lázaro Cárdenas, en México, abiertamente apoyó la causa republicana, adquiriendo armamentos en el mercado internacional destinados al gobierno de $\mathrm{Ma}$ drid. ${ }^{3}$ En Chile, la guerra civil española, en su aspecto diplomático, fue asumida con neutralidad por el gobierno de derecha presidido por Arturo Alessandri Palma (1932-1938). El aspecto del asilo político provocó discusiones en la opinión pública. Carlos Silva Vildósola recordaría en 1939:

"Conviene recordar... todo lo que se hizo y dijo sobre el derecho de asilo que el gohierno de Chile mantuvo dentro de su tradición y de la doctrina invariable de nuestra Cancillería, en la Embajada chilena en Madrid. No sólo la prensa, sino aun parlamentarios desorientados, atacaron con acritud hasta llegar a la injuria, a cuantos representantes de Chile mantenían ese derecho y cumplian su deber de humanidad en resguardo al mismo tiempo de la digni. dad de nuestro país. La intervención del Embajador de Chile en Londres para evacuar de la Embajada a unos cuantos refugiados, dio ocasión para que ese diplomático fuera objeto de las más injuriosas arremetidas de la prensa extremistam. ${ }^{4}$

En octubre de 1938 asumió Pedro Aguirre Cerda la presidencia del país. Con él había triunfado el Frente Popular chileno. Chile, junto a España y Francia, eran los tres países donde se alcanzó el éxito de la alianza táctica de los partidos comunistas con los partidos burgueses progresistas, al tenor de las orientaciones del séptimo congreso de la Tercera Internacional de 1935. ${ }^{5}$ Objetivo principal era detener el avance del fascismo. Cabe hacer notar que el fascismo chileno - representado por el Movimiento Nacional Socialista de González von Marées- unió a su escaso apoyo electoral

3 Viñas, Angel: Las condicionantes internacionales, en Manuel Tuñón de Lara y otros: La guerra civil española. 50 años después. Barcelona, 1986, páginas 140-142.

4 Silva Vildósola, Carlos: España y Chile durante la ouerra. «El Debate». Antofagasta, 22 de abril de 1939.

5 Vid Poulantzas, Nicos: Fascismo y dictadura. La Tercera Internacional frente al fascismo, México, 1976. También, Barria S., Jorge: El movimiento obrero en Chile. Sintesis histórico-social, Santiago, 1973, cap. IV. 
su separación del movimiento fascista europeo en $1938 .{ }^{6} \mathrm{El}$ gobierno de Aguirre Cerda mantuvo la neutralidad diplomática aunque sus simpatías por los republicanos se concretaron en acciones en favor de los exiliados. La labor en este sentido quedó señalada en el barco «Winnipeg», donde le cupo especial participación a Pablo Neruda. ${ }^{7}$ La intervención del cónsul y poeta Pablo Neruda nos introduce directamente en el nivel intelectual-ideológico del conflicto español. La guerra civil significó un compromiso militante activo e internacionalista de lo más granado del mundo cultural hispanoamericano. Nombres principales de las letras continentales apoyaron sin reservas la causa republicana: Alejo Carpentier, César Vallejo, Octavio Paz, Nicolás Guillén, por citar algunos. ${ }^{8}$ Neruda junto a César Vallejo crean las dos mejores contribuciones poéticas hispanoamericanas de la lucha española: el primero España en el corazón, el segundo España aleja de mí este cáliz. ${ }^{9}$

Los escritores chilenos de mayor prestigio de una u otra forma manifestaron su solidaridad a la República española. Pablo Neruda edita, con Nancy Cunard, Los poetas del mundo defienden al pueblo español; revista que continuó lo realizado en Caballo verde para la poesía, pero de modo más militante. Junto a Alberto Romero y Vicente Huidobro representó a Chile en el II Congreso Internacional de Escritores celebrado en Valencia en julio de 1937. Es importante destacar que el señalado Congreso acordó establecer Alianzas de Intelectuales Antifascistas en varias naciones. En noviembre de 1937 se creó la Alianza de Intelectuales en Chile que

6 El 5 de septiembre de 1938 protagonizó un intento de golpe de Estado que fracasó por la devastadora represión gubernamental. Sobre su importancia y relaciones con la inmigración alemana y la Alemania Nazi, véase el documentado trabajo de Olaf Gaudig y Peter Veit: ...Y mañana el mundo entero! Antecedentes para la hitsoria del nacionalsocialismo en Chile. «Araucaria de Chile», núm. 41. 1988, páginas 99-117.

7 Cfr. Cáceres, Leonardo: El «Winnipeg» cuarenta años después, «Araucarla de Chilex, núm. 8, 1979, págs. 47-68.

8 Un registro de sus colaboraciones y las de otros autores en las revistas españolas de la época en referencia lo of rece S. Miguel Losada: Presencia de la literatura hispanoamericana en las revistas españolas de vanouardia: 1918-1939, «Anales de Literatura Hispanoamericana», núm. 17, 1988, 41-59.

9 Cfr. artículos de Teobaldo A. Noriega y Julio Calvino en «Cuadernos Hispanoamericanos. Homenaje a César Vallejos» (abril-mayo 1988, núms. 454-455), volumen $\mathrm{I}$. 
congregó a un nutrido y valioso grupo de escritores nacionales, entre otros, Juvencio Valle, Francisco Coloane, Humberto DíazCasanueva, Oscar Castro, etc. ${ }^{10}$ Los poetas habían publicado ya en 1936 Madre España, Homenaje de los poetas chilenos, notable antología lírica en favor de la República.

Al aporte nerudiano se sumaron otras voces de alto valor en la poesía chilena: Pablo de Rokha da a conocer su Imprecación a la bestia fascista en 1937; Vicente Huidobro escribe un poema sobre Dolores Ibarruri, «La Pasionaria», que apareció inserto en la revista «Hora de España». El 12 de octubre de 1937 redacta también en España su artículo España de la Esperanza. "Gabriela Mistral destinó los beneficios de su libro Tala, de 1938, en favor de los niños huérfanos vascos. ${ }^{12}$

Es en este contexto, en el que habrá que ubicar el impacto y las relaciones de la guerra civil española en el mundo católico chileno.

La guerra civil española que nos preocupa no fue el primer acontecimiento hispánico moderno que interesó vivamente a la iglesia chilena. Durante el bienio progresista de Baldomero Espartero, 1854-1856, «La Revista Católica» arremetió contra las medidas anticlericales del gobierno español, dedicando una serie de artículos sumamente críticos. ${ }^{13}$ Por aquel entonces algunos autores católicos españoles, como Balmes o Juan Donoso Cortés, habían

10 Volodia Teilelboim: Neruda, Meridión. 1984, págs. 188-189.

11 Huidobro alli aftrma: «No sólo se trata de España, se trata de la humanidad... Si el pueblo español perdiera la batalla sería el retorno al mono cavernario de la svástica o del hacha... Hoy, en este aniversario del descubrimiento de América, de este magno poema escrito por el nueblo español sobre los océanos y los continentes, el enorme pueblo de ayer ha vuelto a la epopeya y los ojos del universo están fijos en él y llenos de esperanza. Como hijo de tu raza y de estas tierras que arrancaste al misterio, mi emoción te saluda. España dolorosa y sublime, de pie. y nunca de rodillas». Vicente Huidobro, «España de la esperanza en Vicente Huidobro, prólogo, selección y notas de Mario Céspedes, San José, Costa Rica, 1976. págs. 288-289.

12 Remito a mi trabajo: La otra Gabriela Mistral. Cultura, ideología e intimidad en la correspondencia con Zacarias Gómez. «Anales de Literatura Hispanoaınericana», núm. 18, 1989. En prensa.

13 De esa crítica se hizo cargo el encargado de negocios interino de España en Santiago de Chile. Cfr. su oflcio núm. 54, 7 de julio de 1856. Archivo del Ministerio de Asuntos Exteriores, correspondencia, legajo 1.437. Tenemos avanzado un artículo sobre el tema. 
influenciado a algunos teólogos nacionales. ${ }^{14} \mathrm{Al}$ igual que en España la iglesia chilena había resistido los avances del liberalismo. La creación de la Universidad Católica de Chile en 1889 simbolizó el repliegue de la Iglesia en las tareas culturales, pero asimismo la formación de un centro que incentivará la discusión de las materias más urgentes del catolicismo a futuro: la sensibilidad social y la formulación de un proyecto político. ${ }^{15}$

Desde la caída de la monarquía alfonsina, tras la victoria republicano-socialista en las elecciones municipales de abril de 1931, la prensa católica chilena siguió de cerca la evolución de los acontecimientos políticos en España. No pasó desapercibida la fecha de 11 de mayo de 1931: la quema de conventos e iglesias en Madrid y en otros lugares. Si bien la instauración de la república y sus apoyos ideológicos traducían una política hacia la Iglesia, ${ }^{16}$ sobrevino por la época un gran interés por la enunciación ideológica de la «Hispanidad» que la iglesia chilena vio con simpatía, por lo que significaba en relación con España y ciertamente con la religión.

Debe repararse en que por la década de 1930 la gravitación del clero español en el interior de la iglesia chilena era mínima. Del centenar de sacerdotes llegado entre 1900-1920 quedaba menos

14 Vid. Juan Noemi et al: Pensamiento teológico en Chile. Contribución a su estudio. II. Epoca de la reorganización y consolidación eclesiástica, 1840-1880. «Anales de la Facultad de Teología». Universidad Católica de Chile, 1980, vol. XXXI.

$15 \mathrm{El}$ diplomático español Enrique Vallés captó certeramente el hondo signincado de la creación de la Universidad Católica, como un arma destinada a influenciar a la juventud pero también como la abierta lucha política de la Iglesia y los conservadores contra los liberales en el campo cultural. Cfr. oflcio núm. 43, Santiago de Chile, 4 de abril de 1889. Archivo del Ministerio de Asuntos Exteriores, Madrid, legajo 1.439 .

Para mayores antecedentes remito a mi trabajo Las relaciones culturales entre España y Chile durante el gobierno de José Manuel Balmaceda. La politica del reencuentro finisecular, que aparecerá en «Anales de la Universidad de Chile. Estudios en honor del profesor Alamiro de Avila Martel».

16 El 9 de diciembre de 1931 fue aprobada una nueva Constitución, donde se estableció la no existencia de una religión offcial del Estado; en octubre de 1933 se decretó el cese de la actividad docente de la Iglesia. En enero de 1932 se había disuelto la Compañia de Jesús y habían entrado en vigor las leyes del matrimonio civil, de divorcio y de secularización de los cementerios. Cfr. Ramón Tamames: La República. La Era de Franco, Madrid, 1976, págs. 179-185. Historia de España Alfaguara VII.

Desde mayo de 1931 el cardenal Segura, primado de España, se opondrá resueltamente a la república, actitud que le valió ser expulsado en junio de ese año. 
de la mitad, pues habían fallecido sesenta, y un diez por ciento había retornado a la península. Su influencia intelectual era escasa, pues estuvo dedicada al servicio pastoral, como curas rurales, capellanes, etc. ${ }^{17}$ Las orientaciones teológicas y pastorales dominantes eran de procedencia francesa.

La concatenación de los acontecimientos político-socio-religiosos en 1936-1939, pusieron de relieve una vez más el cómo se es católico o anticlerical en España, hasta devenir el conflicto también en una guerra de religión. ${ }^{18}$ Por más que Antonio Machado, puntualizara, hacia 1938, que «es España el país donde más y mejor se blasfema... la blasfemia es un acto de fe», ${ }^{19}$ su opinión y otras similares no lograron alterar la imagen de la persecución religiosa de los primeros meses del conflicto en la zona republicana. Pudieron más el patetismo veraz de los incendios, saqueos de bienes y asesinatos de religiosos y religiosas de la iglesia española. Aquello decidió al episcopado chileno unánime y públicamente a situarse al lado de la iglesia española y por esa vía en el campo franquista.

En el acercamiento y examen de los sucesos españoles tendremos en cuenta tres niveles de conocimiento y de relaciones entre la iglesia chilena y el bando nacionalista: 1.' Las relaciones institucionales entre la iglesia chilena y el bando nacional; $2 .^{\circ} \mathrm{El}$ credo cultural franquista y el reflejo de la guerra en la creación intelectual chilena, y 3..$^{\circ}$ La concepción de cruzada de la guerra civil y su discurso político.

Nuestras fuentes principales son: «La Revista Católica», «Organo de la Provincia Eclesiástica Chilena»; «El Debate», «Semanario Social-Cristiano. Organo Oficial de la Asociación de Jóvenes Católicos» de Antofagasta, el segundo periódico católico del país

17 Vid. Cándido Lorenzo Llorente: Añoranzas, Prólogo de Pío Alberto Fariña. Santiago, 1936. También el comentario bibliográfico de José M. Corral en aLa Revista Católica», en adelante (R. C.), 18 de enero de 1936, núm. 802, págs. 39-41.

18 CPr. Pierre Vilar: La guerra civil española, Barcelona, 1986, sobre la «imputación a lo espiritual», págs. 33 y ss. También Angel Viñas: Las condicionantes internacionales, ...: La guerra de religión, págs. 163-165.

19 Prólogo a Poemas de Alfonso H. Carrasco, citado por Robert Marrast: Antonio Machado: Tres nuevos textos rescatados (1937-1938), «Insula», Madrid, febrero-marzo 1989, núms. 506-507, pág. 55. 
en importancia; ${ }^{20}$ «Hacia el Ideal», «Revista Mensual. Organo de la Asociación de la Juventud Católica Femenina», órgano nacional de esa asociación. Se editaba en Santiago.

Las tres publicaciones estaban sujetas a censura eclesiástica lo cual refleja con mayor propiedad el pensamiento eclesial de entonces y asimismo las inquietudes del catolicismo laico.

\section{LAS RELACIONES INSTITUCIONALES ENTRE}

IA IGLESIA CHILENA Y EL BANDO NACIONAL

El cuadro de persecución religiosa que vivió la España republicana, desde el día del alzamiento militar nacionalista, ${ }^{21}$ decidió a la iglesia chilena a solidarizarse ese mismo año con la jerarquía eclesiástica española. ${ }^{22} \mathrm{Y}$ éste fue el camino normal sin más alter. nativas. Con antelación había tomado posición frente al surgimiento de la República, y muy en especial desde la subida al poder del Frente Popular español, al aceptar, vía reproducción, la interpretación de los hechos realizados por las revistas «Razón y Fe», de Madrid, y "Criterio», de Buenos Aires. Esto revela a su vez la existencia de un canje con publicaciones eclesiales de otras naciones, ejecutado por medio de «La Revista Católica» y «Hacia el Ideal», por acopiar algunos ejemplos. Las mencionadas revistas extranjeras junto a otras de congregaciones religiosas españolas alimentaron las informaciones del panorama político-religioso que se vivía en España. El inicio del conflicto se tradujo en la interrupción del canje con las publicaciones religiosas editadas en la España republicana. Podemos indicar que el referido canje sumado al testimonio de los sacerdotes que, avecindados en Chile, vivieron la experiencia hispánica, señaló el nivel básico de las relaciones entre ambas iglesias. En el nivel superior estuvieron las comunicaciones entre ambos episcopados. En un nivel intermedio podemos localizar los nexos mantenidos entre las ramas de la Acción Católica

20 \&l Diario Ilustrado», el principal periódico conservador-católico de la época, en su edición de 27 de agosto de 1937, lo calificaba ken importancia el segundo peribdico católico en el pais». aEl Diario Ilustrado» no estuvo sujeto a censura eclesiástica.

21 Vid. Hugh Thomas: La Guerra Civil española, Paris, 1976, págs. 193-197.

22 Infra nota 43. 
Chilena, establecida el 25 de octubre de 1931, y los organismos dependientes del Gobierno de Franco.

Los jóvenes de las generaciones de 1918 y 1928 importantes en la formulación de un programa político-social en el interior de la Acción Católica, ${ }^{23}$ influyeron decisivamente en el ideario de sus congéneres provincianos, adscritos al organismo eclesial por medio de las publicaciones «Revista de la Juventud», «Estudios» y «Revista Universitaria», de la Universidad Católica de Chile. ${ }^{24}$ En Antofagasta, en agosto de 1932, aparece el periódico «El Debate», ${ }^{25}$ que, tempranamente, enjuicia la situación de la República española. ${ }^{26}$

23 Cfr. Fernando Aliaga Rojas: El pensamiento de los jovenes fundadores de la Acción Católica Chilena. «Anuario de Historia de la Iglesia en Chile», vol. 3 , 1985, págs. 9-31. Entre los exponentes de la generación de 1918 figuraron Eduardo Cruz. Coke, Francisco Vives Estévez, Pedro Lira Urquieta, Ricardo Boizard, etc. La generación de 1928 contó con Eduardo Frei Montalva, Bernardo Leighton, Julio Philippi Izquierdo, Jaime Eyzaguirre Gutiérrez, Alfredo Bowen Herrera, etc.

24 A las revistas señaladas estuvieron suscritas en su generalidad la Acción Católica de provincias, a través de sus distintas ramas. eLa Revista Catolicas estuvo en la mayoría de los obispados y vicariatos, por ser el órgano offcial de la Iglesia y figurar en ella los decretos, orientaciones, etc. del episcopado. Los redactores de las publicaciones indicadas fueron formados en la Universidad Cat6lica, y mantenían vínculos estrechos con ella. De esta forma, v. gr. al crearse en algunas ciudades las Asociaciones de Amigos de la Universidad Católica, como en Antofagasta, en noviembre de 1927, se pudo recepcionar «Estudios» y aRevista Universitaria». Hemos podido apreciar - al trabajar en los fondos documentales del Arzobispado de Antofagasta -- las colecciones de la «Revista Católica», volúmenes de «Estudios», «Revista Universitaria» y ejemplares de $\alpha$ Razón y Fe», del decenio de 1930.

25 Antofagasta fue una de las ciudades que tuvo uno de los grupos de la juventud católica más influyente en el acontecer nacional, compuesto por Edmundo Pérez Zujovic, Radomiro Tomic Romero, Juan de Dios Carmona, etc. Pérez Zujovic fue vicepresidente de la república durante el gobierno de Eduardo Frei Montalva, y el primer director de $\ll$ El Debatex. Hemos estudiado la génesis, desarrollo y desaparición del periódico (1932-1947) en Signiflcación $e$ interpretación histórica de la prensa y el periodismo católico en Antofagasta. (Iolesia, realidad social e ideologia». En prensa.

26 Además de las publicaciones señaladas en la nota 24, «El Debate» tuvo a su disposición los volúmenes del Apostolado de la Prensa de Madrid, cuya serie se inició hacia fines del siglo XIX. La colección que hemos podido ver está casi completa en la biblioteca central del Arzobispado de Antofagasta. En aquellos ejemplares figuraban artículos sumamente criticos al ideal republicano, a via de ejemplo. en el volumen CLXVII, noviembre de 1905 , se insertó «La República española pintada por si misma donde se anejaban las críticas de las personalidades politicas al llamado sexenio democrático, sobrevenido en 1868.

En $1932 \ll E l$ Debate» destinó los siguientes artículos a la aclualidad española: «Blasco Ibáñez murió católicamente» (10 de septiembre), «El crucifjo expulsado de la Escuela» (15 de octubre), «¿Ha dejado Fspaña de ser católica?» (7 de enero de 1933). 
¿Cuál fue el impacto —y la interpretación — del ascenso del Frente Popular en España en el ambiente católico chileno?

En abril de 1936 «La Revista Católica» aludía a la abundancia de juicios sobre la materia, pero reconocía «que todos los hechos trascendentales en la vida de un país siempre entrañan lecciones elocuentes que otros países pueden aprovechar». ${ }^{27} \mathrm{~A}$ través de un artículo de monseñor Gustavo J. Franceschi se tuvo el primer análisis sobre el resultado de las elecciones. El trabajo es serio y muy perspicaz. Plantea que el resultado traduce la «disposición espiritual de un pueblo». Y en España, a sabiendas del programa anticatólico de la izquierda, la mayoría de los ciudadanos ha llevado al la «Cámara a quienes se comprometieson a ejecutarlo», o sea, el programa anticatólico. La mayoría por «anticatolicismo o por acatolicismo ha consentido positivamente que la Iglesia sea perseguida. Esta es la realidad. Se dirá que han sido engañados. ¿Cómo ha logrado hacerlo una minoría? ¿No había clero, órdenes religiosas, periódicos, radio difusoras, instituciones, organismos? ¿No podían hablar los unos como los otros? ¿Por qué no se han aprovechado los medios de que se disponía ý que tenían su apoyo en una multisecular tradición?». Para el autor, el problema de España, antes que una cuestión política, lo es de apostolado. La Iglesia no había sido capaz de buscar soluciones a las clases proletarias, mientras las clases dirigentes habíanse escudado detrás de ella para «vincular sus intereses a los de la institución fundada por Jesucristo, para salvar su posición». La conjunción de la Iglesia y la monarquía -al ser el pueblo republicano - ha significado el alejamiento de éste de la Iglesia. A diferencia de España, la acción de la Iglesia en Francia, realizando un apostolado integral sin mezclarse en política, permitía contar con la influencia del «hecho religioso» en aquel país. Esto, vaticinaba Franceschi, hará que el probable triunfo

27 Religión y Ciencia. Las elecciones de España. Apreciaciones del resultado de las últimas elecciones en España, «R. C.». 26 de abril de 1936, núm. 807, págs. 244-250. La revista chilena calificaba a Gustavo J. Franceschi, asacerdote de prestigio en nuestro mundo intelectual». Los artículos de Franceschi Pueron reproducidos también en «Estudios». Sobre la revista «Criterio» de Buenos Aires, Enrique Dussel se refirió a ella fugazmente en América Latina y conciencia cristiana, Quito, 1970. pág. 87. 
frentepopulista en Francia, «será una victoria del izquierdismo social y económico, pero gracias a la prudencia de los obispos no lo será del sectarismo antirreligioso».

El análisis de Francischi fue contestado por José M. Corral, por cuanto era aceptar que «España ha dejado de ser católica». ${ }^{28}$

Un tercer artículo, antes del pronunciamiento militar de Franco, vio luz en «La Revista Católica». El artículo en cuestión La última lección había aparecido en «Razón y Fe» en abril de 1936. En él se reparaba en la «crisis del patriotismo» evidenciada en la despreocupación por el bien común, los desengaños por la democracia parlamentaria, «la misma concepción pacifista de la neutralidad a toda costa como un cómodo reposo adquirido al precio de la dilapidación de nuestro inmenso patrimonio colonial y aun de la humillante cesión del propio territorio»; la «crisis económicosocial» y el aspecto «moral y religioso de la crisis actual». Concluía el articulista que el destino de España estaba ligado a la Iglesia y «que sólo el heroísmo de los católicos españoles ayudado de la gracia divina, puede transformar esos incendios funerarios de nucstra fe en la aurora de una nueva era cristiana». ${ }^{29}$

Puede decirse que el movimiento insurreccional de Franco, Mola y de los otros generales nacionalistas fue recibido como la reacción natural, patriótica y católica ante los atropellos de que eran objeto los religiosos y los bienes eclesiales. España era el único país que podía exhibir mártires por la causa de Cristo. ${ }^{30} \mathrm{Y}$ la dua-

28 Cfr. José M. Corral: Panorama de España, «R. C.». 9 de mayo de 1936. núm. 808, págs. 314-320.

29 La última lección. Comentario electoral de España, $₫$ R. C.», 27 de junio de 1936, núm. 811, págs. 459-464. El subrayado es mío.

30 Vid. Gustavo J. Franceschi: ¿Son mártires los españoles muertos en la persecución? (Juicio de «Criterio a la luz de la teología), «R. C.». 24 de octubre de 1936, núm. 819, págs. 439-444; Una carta del Padre Prudenció de Salvatierra, colaborador de la Revista -..... «R. C.», 14 de noviembre de 1936, núm. 820, páginas 486-488.

«El Debate», entre fines de 1937 y primeros meses de 1938, publicó una seric de artículos a denunciar la persecución religiosa: «La obsesión del crimen persigue a los rojos» (25 de diciembre de 1937); «Como en las catacumbas»: «La España mártir. Los grandes crímenes de los rojos españoles» (ambos de 29 de enero de 1938); «Escenas de la revolución española» (23 de julio de 1938); «En la ventanilla del tren, contemplando El Ebro. La Acción Católica en las trincheras» (28 de enero de 1939). 
lidad española: a la «desoladora impresión que dejan en el ánimo las matanzas de España; la fiera humana ha desplegado su potencia diabólica para el mal, ensañándose sobre los inocentes, sobre los niños, las mujeres, los ancianos, sobre religiosos inermes», ${ }^{31}$ se oponía «el despertar de la Fe en los pueblos: se escucha el rumor de las oraciones de recogidas multitudes que rezan día y noche y como en los tiempos heroicos del cristianismo... se ve a muchos cristiano acercarse temblando de emoción a besar la mano del sacerdote mártir y a encomendarle la suerte de la Patria española». ${ }^{32}$

En noviembre de 1936 «La Revista Católica» bajo el epígrafe «Para la historia de la España roja» dio cuenta de las respuestas recibidas de las instituciones religiosas españolas en su canje normal de publicaciones:

“Al estallar la revolución, no supimos si era necesario suspender esos envíos o no, por lo que nos mantuvimos en espera de los acontecimientos. Han llegado las respuestas deseadas, que son documentos interesantes para comprender el carácter del revolucionario rojo elevado de la sima de su propia miseria, a la alta misión de superior de conventom. ${ }^{33}$

Desde mediados de 1937 en sus páginas aparecieron las extensas glosas de los volúmenes franquistas distribuidos por la Editorial

31 El Horror de España Mártir y La odisea de cinco prófugos salesianos que llegaron a Italia», «R. C.», 24 de octubre de 1936, núm. 819, págs. 424-433.

32 Notas extranjeras. España. La persecución de los rojos, «R. C.», 28 de noviembre de 1936, núm. 821, págs. 550-553.

33 Para la historia de la España roja, «R. C.», 14 de noviembre de 1936 , núm. 820, págs. 488-489. Los números de 27 de julio y 8 de agosto de 1936 fueron devueltos desde la Institución Teresiana de Madrid («Se ausentaron sin dejar señas». (Firma). P. Dumont), de las Escuelas Pías de San Fernando en Madrid a cargo de los PP. Escolapios ( \&Los facciosos de este convento se ausentaron y como es natural no dejaron seĥas»). (Firma) Hipólito Pérez). De la Biblioteca Nacional de Madrid se recibió una tarjeta del director de la sección revistas, escrita en francés, pidiendo el envío de algunos números extraviados. La tarjeta llegó timbrada: «Censurada». Publicaciones religiosas como «Analecta Agustiniana», órgano oflcial de la curla general, o aChispas», de la juventud católica femenina española, permitieron ampliar la cobertura de la persecución religiosa. Cfr. Los agustinos en España y su contribución con sacrificio y con sangre, $\varangle$ R. C.», 24 de abril de 1937, núm. 828; España-Méjico, «Hacia el Ideal», septiembre 1936, núm. 111, págs. 4-5, artículo de Yolanda Brieba, vicepresidenta de la Juventud Femenina Chilena, que cita «Chispas», «recibida recientemente». 
Revista Católica de El Paso-Texas, EE. UU., además de las recibidas desde Buenos Aires. Para los lectores de la publicación quincenal chilena quedó definido el carácter de cruzada y el sentido providencialista que habían asumido las fuerzas nacionalistas-católicas. ${ }^{34}$ Para José M. Corral, la principal pluma que tuvo «La Revista Católica» en el análisis de la realidad española, la literatura aludida debía divulgarse, para contrarrestar la de procedencia marxista que «asfixiaba» al igual que la llamada «neutralista»-que adjudicaba la culpa a la izquierda y a la derecha - como también la propalada por las «agencias masónico-marxistas». ${ }^{35}$

En el órgano oficial de la iglesia chilena se pudo leer textos completos de Franco, Gil Robles y otros exponentes del bando nacional. También jugó un rol importante la Delegación de Prensa y Propaganda del Estado Español (Franquista): muchas de las informaciones divulgadas por la prensa católica tenían a la mencionada Delegación por fuente. «El Debate» celebró la designación de Enrique Martínez Granada, «activo miembro de las Juntas Nacionalistas local y jefe de Falange Tradicionalista Española», como agente consular de la España franquista en Antofagasta. ${ }^{36}$ Desde abril de 1938 se estrechó aún más la colaboración entre el periódico y el organismo de propaganda franquista. «Hacia cl Ideal» dio cabida a la peregrinación a Santiago de Compostela realizada por la vicepresidente de la Juventud Femenina de Acción Católica Chilena: «Eramos más de 3.000 venidas de todo el territorio liberado». ${ }^{37}$ Lo religioso se fundía con lo político. En septiembre de 1937 el Centro Español Nuestra Señora del Pilar de Talca, recibió del «Tte. Coronel Ayudante secretario de S.E. el Jefe de

34 Vid. Libros y Revistas. Viva España!! 1937. Edit. «Revista Católica El Paso-Tejas. EE.UU.», «R. C.», 14 de agosto de 1937, núm. 834, págs. 103-106; Bibliografía. Franco por Joaquín Arrarás. Literatura sobre la Conflagración Española. firmado por José M. Corral («R. C.». 30 de agosto de 1937, núm. 835, págs. 163-166): Bibliografía. Literatura sobre la guerra española, $₫$ R. C.», noviembre de 1937. núm. 839, págs. 466-468. José M. Corral, redactor también de este último comentario. finalizaba: «Vuele nuestro pensamiento de admiración y de cariño a la gran nación. escogida por la Providencia para los grandes destinos».

35 Cfr. José M. Corral: Literatura sobre la conflagración española. «R. C.». 30 de agosto de 1937, núm. 835, págs. 164-166.

36 CPr. $<$ El Debate», 28 de abril de 1938.

37 Noticias del extranjero, «Hacia el Ideal», mayo de 1938, núm. 126, pág. 8. 
Estado y Generalísimo de los Ejércitos Nacionales», los agradecimientos del mismo Franco:

(S.E. agradece mucho las frases amables que le dedican, así como a la noble Causa que defiende y le envía su afectuoso saludo con el ruego de que lo haga llegar a todas las señoritas católicas de la Colonia Española de Talca que componen ese Centro de Nuestro (sic) Señora del Pilar». ${ }^{38}$

Concluyamos que esta conjunción religioso-política de la contienda tuvo su corolario en 1939 cuando el obispo de Antofagasta, Alfredo Cifuentes Grez, de visita en Roma, envió a la revista «Hacia el Ideal», una fotografía donde aparece «la delegada de España presentando al Papa la bandera ensangrentada a la cual el Santo Padre dio un beso como verdadera reliquia de martirio». ${ }^{39}$

Las comunicaciones oficiales entre ambos episcopados se iniciaron en 1936. En aquel año el episcopado chileno remitió un cable al cardenal Gomá, señalándole su simpatía y adhesión a los obispos españoles. La publicación de la Pastoral Colectiva de 1. de julio de 1937 del episcopado español renovó los nexos establecidos. El documento presentó la convergencia de lo político y lo religioso de la contienda. Vicente Cárcel Ortí refiere que fue redactado por el cardenal Gomá a «iniciativa del general Franco y sabiéndolo la Santa Sede, que aprobó el texto. Es un documento serio, bien pensado, redactado y construido, que solamente pretendía mostrar hechos - aunque no decía toda la verdad- sin demostrar tesis, para que en el extranjero se tuviera una visión objetiva y serena de los acontecimientos españoles, cosa que no se consiguió plenamente». ${ }^{40} \mathrm{El}$ episcopado español en el indiciado escrito ponía

38 Carta de contestación del Generalísimo Franco al Centro Español Nuestra Sefrora del Pilar-Talca. (Fotografía). Rúbrica de Franco. «Hacia el Ideal», diciembre de 1937, núm. 128, pág. 9.

39 Carta de Alfredo Cifuentes Grez, obispo de Antofagasta, a Teresa Ossandón (Roma, 15 de mayo de 1939) en ocasión del Congreso Internacional de la Juventud Católica Femenina. Cer. «acia el Ideal», septiembre de 1939, núm. 139, pág. 7. La fotografía se publicó en el mismo número.

40 Cárcel Ortí, Vicente: La Iglesia en la II República y en la guerra civil (1931-39)), en Ricardo García Villoslada (Director): «Historia de la Iglesia en España», B. A. C., Madrid, 1979, V, pág. 379. 
de manifiesto que la Iglesia «se siente amparada por un poder que hasta ahora ha garantizado los principios fundamentales de toda la sociedad, sin miramiento ninguno a sus tendencias políticas... la guerra se ha emprendido... para que resurja el espíritu nacional con la pujanza y la libertad cristiana de los tiempos viejos». ${ }^{41}$

La Pastoral Colectiva fue acogida por la iglesia chilena -en su órgano oficial - como de «orientación definitiva en la apreciación de los motivos, hechos y circunstancias del sangriento drama», pero también del más alto valor «como criterio de certeza, después de las enseñanzas infalibles de la iglesia». De ella podía concluirse:

“1. La causa del movimiento nacional es justa, es la del pueblo sano y cristiano de España, es la causa del orden moral, individual y social, natural y cristiano, es la del genuino laudable tradicionalismo español.

$2 .^{\circ}$ Nos parece... que... se puede inferir lógicamente lo siguiente: La guerra... por ser defensiva de lo más santo y estar inspirada en su generalidad en santos motivos, como la defensa de principios básicos de orden natural, de la religión y de cosas santas, puede llamarse santa como otras guerras de que habla la Biblia y la Historia». ${ }^{42}$

El notable documento del episcopado español redobló la solidaridad católica y afianzó la adhesión al gobierno de Franco en el interior de la iglesia chilena. El episcopado nacional, en su respuesta a la Pastoral Colectiva, recordó:

“La manifestación de simpatía y adhesión que el año 1936 enviamos al Ven. Episcopado Español en cable dirigido a V. Emmia. Rvdma. y para asegurar a todos los Venerables Hermanos en el

41 Citamos el documento por Fernando Díaz Plaja: La Historia de España en sus documentos. El siglo XX. La Guerra (1936-39), Madrid, 1963, págs. $499+524$. La cita en pág. 519.

42 La Voz del Episcopado Español, «R. C.», noviembre de 1937, núm. 839. 391-393. En ese mismo número se insertaron las respuestas del cardenal arzobispo de París, monseñor Verdier, de larzobispo de Westminster, monseñor Hinsley, y del general De Castelnau, Presidente Nacional de la Acción Católica francesa. Cfr. Después de la Carta del Episcopado Español, «R. C.», págs. 394-396. 
Episcopado, al Clero y católicos de España que continuaremos i\%. gando por el triunfo de la causa cristiana en vuestra Patria, Causa que lo es de la verdad, de la justicia y caridad sociales y fuente del bienestar verdadero de los pueblos, y finalmente, que, en conformidad a vuestros anhelos y a vuestra petición, nos esforzaremos en dar a vuestra hermosa Carta Colectiva la mayor publicidad que nos sea posible, para contribuir así al triunfo de la Verdad y de la Justicia en el mundo, a la defensa de la iglesia en la noble España de nuestros mayores y al triunfo definitivo de la Causa de Cristo para bien de la humanidad). ${ }^{43}$

El 10 de julio de 1937 el arzobispo de Santiago de Chile, José Horacio Campillo, ordenaba un día de oración por España. «El dolor de España es el dolor del mundo... todo cuanto la civilización milenaria de nuestra Madre España había levantado para honra de Dios, prez de su raza y provecho de su pueblo, todo se ha convertido en ruinas». La plegaria debía encaminarse hacia el objetivo de que en España renaciera «la paz verdadera, la paz cristiana». ${ }^{4}$

En marzo de 1938 se divulgó la respuesta del episcopado español a lo expresado por el chileno en octubre de 1937. A nombre del episcopado hispano el cardenal Gomá se dirigía a los obispos chilenos:

"El Cardenal Arzobispo de Toledo, Pamplona, 1938.

Excelentísimo y Revedmo. Señor.

Plácenos corresponder con afecto y gratitud a la comunicacion que el Venerable Episcopado de Chile, se ha dignado dirigirnos en prueba de caridad y fraternal cariño. Sé todas las manifestaciones de compasión que se nos han prodigado de todos los ámbitos del

43 Los Obispos chilenos se dirigen al Episcopado español. Carta al Cardenal Arzobispo de Toledo, primado de España, «R. C.», núm. 839, citado, págs. 397-398. Cita en pág. 398. El documento lleva fecha de 7 de octubre de 1937.

También $\star E l$ Debate», en su edición de 30 de octubre de 1937, reprodujo la respuesta del episcopado chileno y una editorial Voces del Episcopado.

44 Arzobispado. Circular que el Excmo. y Rdmo. Sr. Arzobispo de Santiavo envía a los fieles para pedirles un día de oración por España, \&R. C.», 24 de julio de 1937, núm. 833, págs. 37-38. 
mundo católico en estos días de nuestra tribulación, nos han producido indecible consuelo, el estímulo que nos llega de nuestros hermanos de América, nos es particularmente grato, por venirnos de corazones que sienten como propias las congojas de la Madre España.

En correspondencia, los Obispos de España nos honramos en significaros nuestra profunda gratitud asegurándoos que la España Católica jamás olvidará el delicado obsequio de vuestra adhesión de hermanos.

No era menester que expresarais vuestra ansia por nuestra desgracia y vuestra esperanza en el porvenir de España. Nos decía nuestro corazón, aún antes que vuestra palabras, que la jerarquia de América se aprestaria a volcar en nuestra aflicción la efusión de su caridad. Y por lo que a Chile en particular se refiere, no nos son desconocidas las reiteradas pruebas de fino amor que nos habéis dado, y el puehlo español, que tiene noticias de ellas, las agradece vivamente.

La España que renace guarda para América sus predilecciones. Os encarecemos. Vencrables Hermanos, que sigáis rogando para que el Señor nos conceda la paz y con ella el acierto para hacer una España émula de su pasado glorioso y digna de sus mártires y de sus héroes.

Reiterándole mis sentimientos de alta consideación y estima, quedo de Vuestra Excelencia Reverendísima devoto servidor y Hermano. Por el Episcupado Español. I. Cardenal Gomá, Arzobispo de Toledo». ${ }^{45}$

Nos hemos permitido transcribir íntegramente la epístola del cardenal Gomá, puesto que patentiza el grado de adhesión de la iglesia chilena a la española y por ende con la causa nacionalista. Al mismo tiempo corrobora el paradigma de la España católica

45 Carta del Cardenal Arzobispo de Toledo al Arzobispo de Santiago, «R. C.». marzo de 1938, núm. 843 , pág. 188. 
en el sentir de la ejerarquía eclesiástica hispana, así como el eco de la relación de dependencia que otrora hubo entre la Madre Patria y las repúblicas hispanoamericanas.

El CREDo CUltural FRANQUista Y

EL REFLEJO DE LA GUFRRA CIVIL EN

LA CREACIÓN INTELECTUAL CATÓLICA

Los elementos culturales del nacional-catolicismo del gobierno franquista fueron divulgados por la prensa católica chilena. Aunque algunas ideas-fuerzas, como el hispanismo, tenían data precedente a la rebelión nacionalista, alcanzaron máximo despliegue durante el transcurso de la guerra civil. Otras se mantuvieron vigentes en los círculos conservadores más tradicionalistas. También habrá que reparar que singulares episodios inspiraron determinadas creaciones literarias en el interior de la Iglesia.

El hispanismo se constituyó en una de las más gravitantes influencias ideológicas entre la juventud católica y conservadora de la época, viéndose en él medio de «relacionar lo hispano con lo católico y con el modelo corporativista, que se remonta a la ilustración católica». ${ }^{46} \mathrm{El}$ destino del nuevo ideal en Hispanoamérica debía apoyarse en los cimientos de los valores de la Iglesia. El pasado colonial abría las llaves de la comprensión del propio «ser» de América, permitiendo ubicar el lugar de la obra grande de España (su legislación indiana que registra los derechos del hombre, el aporte del conquistador a la comprensión de la idiosincrasia del continente, la lengua, la religión, etc.), y el diseño de la obra providencialista en el porvenir de América: «Todo ello caracterizado por un énfasis apologético, en lo referente a lo hispánico, y con un diseño histórico: con ideales y metas para alcanzar de acuerdo al socialcristianismo». ${ }^{47}$ Son autores como Ramiro de Maeztu y Vázquez de Mella, y otros de la generación de 1898, los que orientan el pensamiento hispanista chileno. En ellos beberán los tradicio-

46 Aliaga Rojas, Fernando: El pensamiento de los jóvenes fundadores de la Acción Católica chilena..., pág. 25.

47 Ibídem, pág. 26. 
nalistas nacionales y recibirán ciertamente en el curso de la guerra civil otras influencias, como el falangismo de Primo de Rivera $v$ los nacionalistas españoles. ${ }^{48}$

La corriente hispanista determinó, de acuerdo con sus postulados, la formación de una visión historiográfica que devino en revisionista al cuestionar incisivamente la labor de la historiografía liberal y positivista del pasado que, todavía seguía rigiendo la enseñanza de la historia nacional. El rescate del pasado colonial, de la herencia global de la cultura española (la generación del poder político, el dogma e influjo católicos, el sentido de unidad nacional bajo una misma autoridad, orden social y valores espirituales, etc.) promovió una escuela historiográfica hispanista, cuyo mayor exponente fue Jaime Eyzaguirre Gutiérrez. Su labor fue sistematizar -por oposición al «pasado glorioso» de la colonia - la decadencia en que estaba sumergida la nación chilena y por ende su historia republicana. Entre los factores de la decadencia nacional, registraba la «baja apostasía interior», su traición al legado hispánico y católico tradicional, la adopción de formas culturales, sociales y políticas extrañas al ser nacional, y la democracia y el capitalismo liberal. ${ }^{49}$

La crítica planteada por los autores tradicionalistas y nacionalistas españoles sobre el pasado reciente liberal, heterodoxo, par-

48 Mario Góngora expresará: «El Hispanismo como una empresa política contemporánea, afirmado por Ramiro de Maeztu, por «Acción Española», el Falangismo de Primo de Rivera; en fln por los nacionalistas durante la guerra civil de 1936-39». Cfr. Mario Góngora: Reflexiones sobre la Tradición y el Tradicionalismo en la Historia de Chile, «Revista Universitaria», núm. 2, junio 1979, pág. 3. También Renato Cristi y Carlos Ruiz: Pensamiento Conservador en Chile (1903-1974), «Opciones», núm. 9, mayo-septiembre 1986, págs. 131-135.

«El Debate», en su artículo ¿Ha dejado España de ser católica? (7 de enero de 1933), daba cuenta de la posición de la intelectualidad católica, representada por Eugenio D'Ors, Ramiro de Maeztu, Eugenio Montes. En su número de 13 de noviembre de 1937 publicaba: «Pavorosas predicciones de Vázquez de Mella y augurios de una nueva Europa católica». El 15 de abril de 1938 reprodujo el artículo de Manuel García Morente Raices históricas del movimiento nacionalista.

49 Las ideas de Jaime E.yzaguirre fueron expuestas preliminarmente en la «Revista de Estudiantes Católicos» y en «Estudios» en la década de 1930. Para su análisis remito a Cristian Gazmuri, La Cosmovisión de Jaime Eyzaguirre, en Cristian Gazmuri et al, Perspectiva de Jaime Eyzaguirre. Santiago, 1977, páginas 94-104. También, del mismo autor, La historia de Chile republicano ¿una decadencia?. «Alternativas», junio 1984, número especial, págs. 123-125. 
lamentario de su país, fue homologada en la prensa católica chilena. ${ }^{50}$ Se aceptó sin reservas la interpretación histórica de los autores tradicionalistas hispanos, y de los nacionalistas de ahora, sobre la decadencia española. En agosto de 1936 se podía leer en «La Revista Católica»:

"La Monarquía española cayó porque sus propios errores de componendas con los partidos avanzados a la vez que su indolencia para afrontar los problemas sociales provocaron su derrumbe. Abandonó el poder sin defenderse para evitar que España se desan. grase en una guerra civil. Con este paso de dudoso patriotismo no hizo más que retardar por pocos años ese desgarramiento que hoy presenciamos.

Pero la indignación de la España cristiana y tradicional no pudo soportar más esta devastación del derecho y de la vida ciudadana. Esta es la historia sucinta de la tragedia española provocada de inmediato por el Frente Popularm. ${ }^{51}$

La visión revisionista de inspiración tradicionalista fue repetida con exactitud por Manuel Fernández Rivas, director de «El Debate», en julio de 1938:

(De los excesos de la política liberal del siglo XIX, se fue formando en la Peninsula el espiritu de la desintegración española. Con la sublevación de Riego, justificada por pruritos constitucionales, se hizo la más alta traición a la patria. El levantamiento de Riego fue obra exclusiva de la masonería para terminar con el imperio español en la América... La guerra de Cuba es otra de las obras maestras preparada por la mafia internacional para completar el exterminio del dominio español.

50 CPr. Rafael Valls: Ideologia franquista y enseñanza de la historia en España, 1938-1953, Josep Fontana (Ed.): España bajo el Franquismo, Barcelona, 1986, págs. 230-24... Estudia la influencia de Menéndez Pelayo y Maeztu.

51 La tragedia hispánica, «R. C.», 8 de agosto de 1936, núm. 814, 140. En abril de 1937 publicó el díscurso de Franco, al inaugurar la radio nacionalista de Salamanca, donde se expone algunos lineamientos interpretativos de la historia de España. Crr. Discurso notable del General Franco, \&R. C.», 10 de abril de 1937. núm. 827, págs. 255-257. 
la primera República de $\mathrm{Pi}$ y Margall, de Castelar, Salmerón. y de Figueras, constituye uno de los experimentos para tantear la posibilidad de derrumbar definitivamente la forma monárquica de gobierno, último baluarte de la unidad española.

Destruido el dominio de Ultramar era menester proceder a des. hacer la unidad política de la nación).. ${ }^{52}$

Para Fernández Rivas el destino de las naciones americanas estaba enlazado a la cultura hispana. Para él la nueva España que emergía con Franco incrementaría las relaciones con Hispano américa:

"No sólo un acercamiento, sinn que un enlace estrecho con sus hijos de América, a los cuales incorporó con su mentalidad y cultura a la civilización occidental. Los hispano-americanos debemos impulsar desde acá esta labor. Guerra al Indoamericano retrógrado y disgregador de la misma cultura que le está reservado a este continente. Nada de retrocesos. No debemos mirar hacia los incas ni hacia los aztecas. E'stamos dentro del mundo civilizado por obra de España y con ella debemos continuar los designios de nuestra lengua, de nuestra religión, de nuestra cultura). ${ }^{53}$

La aceptación de los autores católico-tradicionalistas y nacionalistas supuso en la prensa católica una fortísima crítica hacia los intelectuales republicanos, entre los cuales se encontraban José Ortega y Gasset y Miguel de Unamuno. Para Fernández Rivas, la decadencia española y el inicio de la guerra civil fue en parte responsabilidad de la intelectualidad española:

52 Fernández Rivas. Manuel: A España en su tercer año triunfal, «El Debate», 16 de julio de 1938.

53 Idem: Boceto del nuevo Estado Español. «El Debate», 22 de abril de 1939. Los subrayados son mios.

En abril de 1938 aLa Revista Católica» anuncia que el triunfo definitivo de la España Católica de Fernando e Isabel «será una realidad» y ade la Nueva España surgirá un mejor entendimiento con nuestras repúblicas que nos permitirá gozar nuevamente de la bienhechora influencia del espiritu ibero». Cfr. Comentario del Mes. Madrid. Valencia, Barcelona, «R. C.», abril de 1938, núm. 844, pág. 309. 
“Una handa de pedantes, estilo Unamuno, Ortega y Gasset, Madariaga, Blasco Iháñez, Soriano y otros más brindaban los escapara. tes de las librerías con sus libros cuajados, por lo general, de retruécanos, frases difícilmente comprensibles, intencionadamente embrolladas, para epatar al lector con una intelectualidad carente de un sentido profundamente nacional. $Y$ en ese ambiente de desorden político, social y económico, en esta molicie del subscons. ciente de los intelectuales españoles, en esta nación envenenada por ideas anti-españolas nació la República».. ${ }^{54}$

La formulación de la responsabilidad de la intelectualidad - con el consiguiente ataque - alcanzó su máxima expresión en «La Revista Católica», donde, en mayo de 1939, se les acusaba:

“Los mayores culpables de la catx́strofe española han sido los famosos intelectuales.

Con una inconsciencia y una perfidia de que no hay ejemplo predicaron la rebeldía, la irreligiosidad, el anarquismo, la unión con Rusia roja. Envenenaron al pueblo con su prensa, volantes, libros, folletos, opúsculos, revistas con un tezón criminal, casi diabólico alcanzando el veneno hasta las más lejanas aldeas y villorrios del país.

Fue obra lenta de penetración, de infiltración en que se iba des. truyendo todos los principios eternos y salvadores de Hogar, Religión, Tradiciones, Patria, Disciplina.

Demagogos especializados en la palabra y en la seducción, comple. taban la obra del periódico y del volante y daban conferencias vulgarizando el ideal marxista: odio a la clase dominadora, odio a la iglesia, odio a la autoridad, odio a Dios.

Los caudillos intelectuales trabajaḅan para sí: los Ortega, Ortega Gasset, Unamuno, Alcalá Zamora, Maura, Prieto Caballero, Osorio Gallardo. Corrompieron al pueblo hasta la misma médula: le arrancaron la Fe en Dios y la Fe en la tradición y lo desvincularon con el Pasado. Cuando vino la derrota, tal como los pastores

54 Fernández Rivas, Manuel: A España en su tercer año triunfal... 
mercenarios, todos huyeron para salvar el pellejo y la bolsa bien repleta.

Le han buscado refugio aquí en Chile o en México, otro pais estrujado por el socialismo marxista.

Todos ellos son indeseables pues llevan en sus convicciones, veneno violentísimo para infiltrarlo en el pueblo que los albergue. A la miseria fisiológica que nos abruma nos viene de las nubes este regalo de indeseables). ${ }^{55}$

Se propugnó como ideal en la formación femenina el ejemplo de las mujeres católicas españolas:

“No leeremos novelas, ni periódicos, ni revistas, ni aún las de modas, ni acudiremos a presenciar películas de cines, ni representaciones teatrales, si no nos consta que están aprobadas por la Autoridad Eclesiástica). ${ }^{56}$

Al rechazo enérgico a las actividades de los escritores chilenos pro republicanos, ${ }^{57}$ las páginas de la prensa católica dispensaron lugar a los textos líricos, discursos y hasta una obra de teatro. En ellos se exaltaron dos temas muy significativos para la causa nacionalista: la persecución religiosa y la defensa del sitio del Alcázar de Toledo.

En los versos del presbítero Pedro Claramunt Parés se asoció la imagen del niño huérfano de la guerra con la madre viuda-Españala cual implora por. sus hijos-los españoles:

55 Ojeada sobre el mundo. De España, «R. C.», mayo de 1939, núm. 857 , págs. 353-354. El subrayado en el texto. Similares conceptos habia empleado Giménez Caballero en Arte y Estado: «De la razón vamos pasando a un camino mucho más nuestro, conocido, seguro y eflcaz, el de la fe... El abuso de la razón suele dar: el indeciso, el cobarde, el agnóstico, el perdido... La fe, todo lo que puede provocar es el fanático. Pero un fanático tiene todo resuelto en la vida. Es el destino superior del hombre». Giménez Caballero, E.: Arte y Estado, Madrid, 1935, pág. 14.

56 Además de esto: renuncia al corte de cabello, usar vestidos sin escote alguno, de manga larga, falda larga y holgada; no bailar en público ni en salones cerrados, etc. Cfr. El ejemplo de las mujeres de Espana, «R. C.», enero de 1938, núm. 841, pág. 60. Después de transcribir los acuerdos, la redacción de la revista agregaba: «Que imiten este e.jemplo las mujeres chilenas». 
"Hoy os habla un huerfanito sumido en dolor profundo porque ha perdido en el mundo su dicha y felicidad.

Mi padre estaba en la guerra;

mi madre enferma y llorosa, cual descarga tempestuosa, triste nueva recibió

Españoles: una madre vestida de luto, hoy llora, y por sus hijos implora Vuestra generosidad. Su voz a todos conmueve, pues para nadie es extraña: es vuestra Madre, es España, todos la habéis de escuchar'). ${ }^{58}$

En agosto de 1936 un religioso jesuita dedica un extenso poema a sus hermanos españoles, viendo en los jesuitas deportados de España el puente espiritual entre la península y América:

«Hermanos bienvenidos!

Llegáis a vuestra casa:

57 Ver lo anotado en el parágrafo II: «La guerra civil e Hispanoamérica. Lo político y lo cultural».

Marta Brunet, en una encuesta de la revista elig-Zag (14 de agosto de 1936), sobre la actualidad española declaraba: aSi la guerra civil logra de una vez por todas librar a España de la Barra dura y opresora del clericalismo, del fascismo y de la monarquía, sus mayores horrores y dolores estarán compensados por el porvenir que le vales.

La \&Revista Católicas se preguntaba si era esnobismo o estupidez que el público asistente a los teatros centrales de Santiago aplaudiera las películas en favor de la República española: \& manos con sortijas y perfumadas no han vacilado en aplaudir». CPr. La última quincena. ¿Esnobismo o estupidez?, \&R. C.», 29 de agosto de 1936, núm. 815, pás. 192.

58 El nifto huérfano. Recitada en la flesta en honor de Espafia, el 12 de octubre en el Teatro Municipal de Iquique. «R. C.», 20 de octubre de 1937, núm. 837, págs. 290-291. 
Venid ! porque en las venas

del Nuevo Continente, junto con sangre indígena, bulle la sangre ardiente del Cid y San Fernando Pelayo y Roger de Flor. Venid! porque en las rocas de las andinas cumbres, repiten de los ecos las gayas muchedumbres, las sílabas triunfales del habla de León.

Venid! os esperábamos:

mirábamos la horrenda tragedia de ultramar: oímos los rugidos de la sangrienta fiera.

Y tornarán de nuevo los bravos escuadrones, $\mathrm{Y}$, al son de los clarines, al viento los pendones, un día, como en España todo púrpura y luz, traspasarán triunfantes las pirenaicas cumbres, $y$, en medio de los vítores de inmensas muchedumbres, desplegarán su enseña la enseña de la (ruz). ${ }^{59}$

59 F. D., S. J.: Mártires del Papa Rey. Dedicada a los jesuitas deportados de España. «R. C.». 8 de agosto de 1936, núm. 814, págs. 129-130. 
El Romance de muertos de la guerra de José María Pemán, uno de los máximos exponentes de la poesía franquista, ${ }^{00}$ fue publicado por «La Revista Católica» en enero de 1938.

En el curso del año 1936 se erigen los símbolos colectivos del heroísmo en los bandos republicano y nacionalista. Si la defensa de Madrid - «la epopeya central de la guerra», a decir de Raymond Carr-, ${ }^{61}$ simbolizó la valentía y el heroísmo de las fuerzas republicanas; el Alcázar de Toledo patentizó aquellos valores en las fuerzas nacionalistas. Ambas proezas fueron celebradas en el periodismo de la época.

El 2 de noviembre de 1936 fue estrenado en el Seminario Pontificio de Santiago el drama en tres actos y un epílogo El Alcázur de Toledo. Su autor, el presbítero Aníbal Carvajal, «profesor del Seminario y admirado dentro y fuera de él como orador y dramaturgo, carmelita e hispanista», habíase basado en las noticias difundidas desde Burgos y Sevilla. La obra era elogiada descle el punto de vista de la escena y de la apologética. Duraba tres medias horas su representación. Un cronista del drama, después de elogiar las repetidas representaciones (dos en la primera quincena de noviembre) hacía votos para que el arte del dramaturgo «puesto al servicio de la raza y de la fe» pudiera llegar a más amplios auditorios. ${ }^{62} \mathrm{Y}$ aquello se cumplió pues la obra fue publicada íntegramente por «La Revista Católica» en el mes de diciembre de 1936 . $^{63}$

Centrada alrededor de la resistencia del Coronel Moscardó y su contingente, concluye en el ajusticiamiento de su hijo Luis. Determinados personajes centrales expresaban los valores en juego desde el prisma nacionalista: el coronel, los cadetes Pedro y Miguel, herederos del legendario heroísmo, de las tradiciones y las glorias

60 Su Poema de la Bestia y el Angel, 1938, trazó todo un estilo de la composición lírica nacionalista. Vid. Manueł Tuńón de Lara: Cultura y culturas. Ideologias $y$ actitudes mentales en Manuel Tuñón de Lara y otros, La guerra civil en especial, págs. 298-299.

61 Carr, Raymond: España, 1808-1939. Barcelona, 1979, pág. 656.

62 C. H. D.: Un homenaje a los héroes españoles: El Alcázar de Toledo, «R. C.», 14 de noviembre de 1936, núm. 820 , págs. 489-490.

63 El Alcázar de Toledo. Drama en 3 actos y Epílogo, del Pbdo. Dn. Aníbal Carvajal, «R. C.», 26 de diciembre de 1936, núm. 823, págs. 642-663. Su autor la concluyó el 20 de octubre. 
del pasado; el capellán fray Francisco, patentiza el valor espiritual de la «cruzada»; el niño Pelayo, la niñez guiada de los valores trascendentales y esperanza del futuro. Como obra apologética de la causa nacionalista, exhibe el antagonismo de los «valores» positivos de aquel bando, y los «valores» negativos de los republicanos. La interpretación de la guerra como cruzada y providencialista recorre todos los actos y escenas del drama. De acuerdo al guión de la obra, la presentación de los valores positivos y negativos, como las ideas-fuerzas, es la siguiente. Los defensores del Alcázar y las fuerzas nacionalistas representan:

Dios-ampara (Reina Pilar, $\Lambda$ póstol Santiago)-armas: oración, invocación, misa: Patria-Glorias pasadas=Alcázar-Reliquia (patrimonio, heroísmo, honor, caballero)=buena conciencia-alegríaluchar: Nuevo Periodo de la Historia =Guerra: Purificación nacional.

La representación de los valores negativos con sus consiguientes ideas-fuerzas que simbolizan los atacantes del Alcázar y las fuerzas republicanas, conlleva la lectura que sigue:

Demonio-guía (Lobos sanguinarios, reptiles, bichos dañinos)-armas: barbarie, confusión, blasfemia: Destrucción reliquias del Pasado (bandera republicana: vergüenza nacional) $=$ abortos del Infierno/esclavos de Moscú: forajidos, perfidia, engaño: Democracia soberana del Pueblo $=$ Crimen, Asesinatos.

Conjuntamente con esta exposición ideológica del conflicto español, se ponía de relieve en el estreno del drama, la asistencia de algunos militares. El citado cronista dice en este punto: «No ha faltado quien encuentre demasiado rezadores a los soldados. El representante del ejército juzgó eminentemente militar el drama, y el heroísmo histórico de sus personajes, sólo se explica por su religiosidad acendrada de que el cable judío da fe». ${ }^{\text {th }} \mathrm{Y}$ es precisalmente un militar, el teniente coronel Florencio Felíu Velasco, del Estado Mayor del Ejército, quien escribe un extenso artículo sobre

64 Supra nola 62. El subrayado es mío. 
El Alcázar de Toledo que se pudo leer en el mes de abril de 1937 en «La Revista Católica». El autor reseña la historia de Toledo desde la época romana hasta arribar a la defensa del coronel Moscardó:

(El 18 de julio de 1936, la Península entera se siente sacudida por un estallido revolucionario. La revuelta lucha por el orden y la tradición, por la religión y el nacionalismo.

El Gobierno defiende su autoridad, las leyes vigentes y sus ideas sociales.

Alimentada en las glorias tradicionales de la raza, imbuida en los principios de orden y disciplina militar y social, la Academia de Infanteria se cobija bajo las banderas de las revolución...

Sesenta días de fiera resistencia presentan una lección de heroísmo no registrada hasta ahora en los anales de la humanidad...

Entre las llamas y la metralla se destaca la figura sobrehumana del Coronel Moscardó...

Es la tradición heroica de la raza; es el alma caballeresca de la España.

El heroísmo se ha impuesto sobre el odio; la entereza y la voluntad han sido más fuertes que las armas; una vez más el alma del Cid ha llevado sus caballeros a la victoria). ${ }^{65}$

Cabe hacer notar que el Seminario Pontificio respiró un ambiente impregnado de fuerte hispanismo, reflejado en la divulgación de ese credo por Aníbal Carvajal, Carlos Hamilton y muy especialmente por la presencia del dramaturgo y poeta español Eduardo Marquina entonces en la cumbre de la dramaturgia española». "6 En la distribución de premios en el Seminario Pontificio en 1936 invitado especial fue Eduardo Marquina:

65 El Alcázar de Toledo. Por el teniente-coronel don Florencio Feliú Velasco, del Estado Mayor del Ejército, «R. C.», 10 de abril de 1937, núm. 827, 231-235.

66 Escobar, Hipólito: La cultura durante la guerra civil, Madrid, 1987, pág 238. Además señala: «Eduardo Marquina, el creador del teatro poético, que regresó de Argentina, donde estaba cuando se iniciaron las hostilidades para defender a los nacionalistas» (pár. 239).

José Corral se refería a Carlos Hamilton como adelicado hispanófllo». Cfr. José M. Corral: Distribución de premios en el Seminario Pontificio, $\alpha R . C . \bowtie, 26$ de diciembre de 1936, núm. 823, págs. 623-624. 
"Sala adornada con el tricolor; con la cruz gamada del Rin, con el rojo y gualda español, con el blanco y amarillo de la Santa Sede y con otros lábaros en homenaje a los alumnos del Seminario que, a más de ser interdiocesano, cobija cabe sí a alumnos de cinco naciones sudamericanas...

El coro del Seminario, dirigido hábilmente por el presbítero don Fernando Larraín, ejecuta en una forma brillante Tannhäuser de Wagner. El Allelluia del Oratorio II Messia (Händel) de muy difícil ejecución cautivó la atención del escogido público...

Invitado (Eduardo Marquina) a firmar el Album de los visitantes ilustres del Seminario, reflejó esos anhelos y esas nostalgias y esas amarguras en el siguiente cantar:

"Religión, virtud y fe

Se juntan en esta casa:

Quién devolviera el latido

De estas tres cuerdas a España!»." ${ }^{\circ 7}$

Registremos también que dentro de ese espíritu de hispanismo, con todo su significado ideológico de la época, la principal publicación eclesial, resaltó además esa conjunción Dios-Patria, dando cabida, por ende, a las expresiones castrenses en las actividades culturales de la Iglesia - que hemos aducido en líneas superioresy destacando a los hombres de armas católicos, como el general Aurelio Carvallo Casanova. ${ }^{68} \mathrm{~A}$ nuestro juicio, para la Iglesia existían motivos para subrayar enérgicamente los valores trascenden-

67 Corral, José M.: Distribución... Los subrayados en el texto.

68 En su necrología se ponía de relieve su procedencia de «viejos patricios militares, por su madre era sobrino carnal del Arzobispo Casanova... La fe cristiana en su alma... le servía como una norma para su obra educadora y formadora de conciencias en el Ejército... Tenía obras que realizar para el Ejército, para la Patria, para Dios». CPr. J. I. R.: Necrologia. El General Aurelio Carvallo Casanova. «R. C.», 20 de octubre de 1937, núm. 837, pág. 309.

Desde las páginas de «La Revista Católica» se ponderó de adocumento trascen. dental» el escrito del cardenal de Toledo, Isidro Gomá y Tomás: Catolicismo w Patria: use dilucida con sólida doctrina, claridad y elocuencia el concepto del Catolicismo y el de Patria con todas las consecuencias que de estas dos tesis doctrinales se desprenden... Esta Pastoral debería ser conocida en toda la cristiandad y meditada». Cir. Ojeada sobre el mundo. Un documento trascendental, \&R. C.». mayo de 1939, núm. 857, págs. 352-353. 
tales para ella, Dios; y de las fuerzas armadas, Patria, pues consignaba «La Revista Católica» que el paralelo con la tragedia española no estaba lejos. ${ }^{69}$

\section{LA CONCEPCIÓN DE CRUZADA DE LA GUERRA CIVIL Y SU DISCURSO POLÍ́TICO}

Desde el conocimiento de la sublevación de Franco en julio de 1936, la iglesia chilena visualizó la contienda como un acontecimiento de cruzada. Se enunció el conflicto recién originado:

"I a Madre Patria, se halla levantada en armas: juega en estos momentos el trance más decisivo de su historia. Se define la posición de la cristiana España, puesta en la angusttiosa alternativa de ir a un comunismo demoledor de su orden social, o volver su mirada hacia la ruta que el Señor le ha trazado, de ser tierra defunda de hijos de la Cruz. Confiamos que el Apóstol que defendió directamente a sus devotos en Clavijo contra el poder musulmán, intercederá con el Señor en pro de la causa del catolicismo y de la misma civilización».. ${ }^{70}$

Aceptada la interpretación de cruzada, España fue vista por los católicos chilenos como «esa Madre que sabe jugarse la vida por el Ideal... mira hoy sino a la España de ayer y de siempre». ${ }^{71}$

Había una verdadera España y una anti-España, la primera era «La España que defiende su solar, sus tradiciones, su Fe religiosa y su Patria es un paladín del cristianismo y de la cultura católica universal». ${ }^{72}$ Se estaba asistiendo a una guerra santa ${ }^{73}$ y

69 Como en España, estamos también nosotros amenazados de comunismo... hay comunismo en las fábricas, en instituciones fiscales y semifiscales, en la Universidad del Estado y hasta en las fuerzas armadas, que es cuanto cabe». Cfr. La última quincena. Insensatez, $\&$ R. C.», 8 de agosto de 1936, núm. 814, pág. 142. El subrayado es mío.

70 La Revolución de España, «R. C.», 25 de julio de 1936, núm. 813, pág. 93.

71 La última quincena. El día de la Raza. «R. C.», 20 de octubre de 1937, núm. 937, págs. 307-308. También La Voz del Episcopado Español, «R. C.», noviembre de 1937, núm. 839, pág. 391 . 
por lo tanto de cruzada religiosa, lucha entre el bien y el mal, y, dentro de ese contexto, la misión providencialista de España. Todo esto fue ampliamente divulgado por la prensa católica. ${ }^{74} \mathrm{La}$ expresión ideológica de la cruzada alcanzó su culminación en la obra de teatro El Alcázar de Toledo del presbítero Aníbal Carvajal. Además se fue asociando cada día más la simbolización de las virtudes espirituales como de los valores políticos y culturales de los nacionalistas en la figura del Generalísimo Francisco Franco:

«Franco es el jefe. Cruzado de la fe y del honor en esta etapa crítica, acepta la responsabilidad de su actitud... General de generales... diplomático hábil... Franco llevará a España a cumplir los destinos de la raza latina. Franco aplastará el Anticristo de las estepas nortinas, y hará prevalecer la Cruz sobre la hoz y el martillo". ${ }^{15}$

La España nacionalista exhibía «orden, trabajo, alegría, decisión inquebrantable de independizar la patria del yugo soviético,

72 Comentario a Viva España! 1937. de Manuel Galiño. Supra nota 34.

73 «Pero el espíritu español, sólidamente cristiano en sus costumbres, en sus tradiciones, en sus hogares subsistía.

Y vino el experimento comunista: la lucha eterna entre el bien y el mal: la Fe contra la impiedad; Roma o Moscú... y la España, conquistadora y misionera. con la sangre de sus mártires, debía convertir su tierra en un inmenso relicario». CPr. La Experiencia de Eśpaña. «Hacia el Ideal», diciembre de 1940, núm. 154, pág. 6. Al asociarse «guerra santa a la lucha entre cristianos y musulmanes, la presencia de las fuerzas moras al lado de Franco, fue explicada por \&El Debate» en razón «que la guerra civil española no es una contienda de cristianos contra cristianos, sino de individuos que profesan una religión contra los que escarnecen y profanan todo lo que tenga alguna relación con la divinidad. Los moros son mahometanos y profundamente religiosos... Los moros llevaron a Europa la brillante civilización de los árabes... Dios, Patria y Hogar es el lema de moros y cristianos que luchan por la civilización y la cultura... Profundamente religioso, el árabe 0 el moro, profesa un cariño extremado por la tradición familiar con la amplitud del Clan o de la tribu y deflende su tierra con un valor feroz, nunca exento de nobleza e hidalguía caballeresca». Cfr. Les caroó con los moros!. «El Debate». 30 de enero de 1937.

74 Además de los artículos mencionados, cabe agregar: Juan de Guernica O. N. Cap., Los sucesos de España en el plan de Dios. El Excmo. Sr. Irurita ע la M. Rajols, «R. C.», 29 de agosto de 1936, núm. 815, págs. 175-178; «El Debate» publicó el discurso de José María Pemán, pronunciado en Sevilla: Misión histórica providencial de España. Apareció en la edición de 26 de diciembre de 1936.

75 Comentario de José M. Corral al libro de Joaquin Arrarás, Franco, Buenos Aires, 1937), Cfr. Bibliografia. Franco por Joaquín Arrarás, $₫ R$. C.», 30 de agosto de 1937 , núm. 835 , pág. 163 . Los subrayados son míos. 
anhelos de bienestar social y premio justo al verdadero operario». ${ }^{76}$ Por oposición, la España republicana se ve «quitados los oropeles de la propaganda, vacío de ideales, vacío de consistencia, vacío de finalidad».

Los valores exaltados en las publicaciones católicas chilenas como el destino histórico, la raza, el jefe, el ideal religioso, la cruzada, la tradición, honor, caballerosidad, la sangre redentora, la violencia santificada, orden, etc., siguieron de cerca los padrones estéticos-ideológicos de la creación literaria del bando nacionalista. " Ese «cultivo retórico de la embriaguez de estilo» como definiera aquello Dionisio Ridruejo, ${ }^{78}$ produjo un contrapunto en la visión de los regímenes fascistas europeos por parte de la Iglesia: mientras tales conceptos culturales-ideológicos eran utilizados en la exaltación de la 'cruzada' nacionalista, asignándoles hondo y trascendentales significados, se los cuestionó y negó su empleo por

76 Comentario de José M. Corral al libro de Angel Toledo. En España ha amanecido!, en Bibliografia. Litcratura sobre la guerra española, $\alpha R$. C.». noviembre de 1937, núm. 839, pág. 467.

Véase también las impresiones del P. de Salvatierra de su visita a la España franquista. CPr. Notas extranjeras. Una carta del Padre Prudencio de Salvatierra. colaborador de la Revista. «R. C.», 14 de noviembre de 1936, núm. 820, pág. 488.

La prensa católica chilena insistió en el tema de la restauración plena de los derechos de la Iglesia y la comunión de fe de los conductores de la guerra del bando nacionalista. A título de muestrario, cfr. «EJ Debate», Los jesuitas en España (28 de abril de 1938). Profesión de fe de varios jefes espanioles (2 de julio de 1938). El asunto de los católicos vascos y la actuación del Ministro Irujo fueron juzgados como desobediencia a las directrices de la iglesia española y complicidad con los enemigos de España. CPr. La República espafiola y la cuestión vasca (de José María Gil Robles), reproducido en \&R. C.». noviembre de 1937, núm. 839, págs. 427-431. También José M. Corral, Bibliografía. Sobre el clero espafiol, «R. C.», 12 de diciem. bre de 1936, núm. 822. págs. 597-598; Notas extranjeras. La farsa sobre el crimen. «R. C.», 14 de agosto de 1937, págs. 106-108. Trata sobre el Ministro Irujo. Es un artículo tomado de «Criterio», Buenos Aires, 12 de agosto de 1937.

77 Francisco Caudet ha inventariado los contenidos ideológicos de la poesía del bando nacionalista, reparando en el vocabulario especial utilizado («purezai, «Luz», «sangre», agenerosidad», como deniominador común de la poesía fascista espahiola), conceptos como aunidad de destino», ahéroe», kespada-cruz», aluchamuerte»; el uso de palabras,fuerzas, «España», «Caudillo», «Nación», «Religión», «raza», «guerra», «imperio», y el lenguaje religioso (mártires, fe ciega de creyentes, redención, salvación), etc. Vid. Francisco Caudet: Apraximación a la poesia fascista española: 1936-1939, «Bulletin Hispanique», tomo LXXXVIII, 1986, núms. 1-2, páginas $155-189$.

78 Ridruejo, Dionisio: Escrito en Esspaña. Buenos Aires, 1962, pág. 79. Citado por Francisco Caudet: Aproximación a la poesía fascista..., pág. 160. 
la ideología nazi. En la carta de los obispos chilenos al episcopado alemán, de octubre de 1937, se expresa:

"Cuán grande es nuestra pena... ver... cómo la pureza de la verdadera Fe en Dios (subrayado en el texto)... trata de ser sustituida en ciertas esferas, que el gobierno abiertamente favorece, por otros valores vacios de significado espiritual como la raza, la sangre, el suelo, el estado, o los nuevos mesias del concepto panteistico y a la vez materialista de Estado-Dios, hombres positivamente de valer y patriotismo admirable pero tristemente desviados y a quienes se les consagra un culto semidivino por las muchedum. bres ensoberbecidas y fanatizadas! Se ha tratado de equiparar y aun de poner encima de Cristo, Dios y Hombre Redentor de toda la humanidad a una criatura humana, que la muerte ha de llevar al polvo del sepulcro... condenamos con energía... la paganización $y$ sentido laico dado arbitraria y audazmente a palabras y expresiones, cuyo contenido real es y ha sido siempre de hondo sentido cristiano, como (revelación», "(fe), (inmortalidad), (pecado original», "humildad», "gracia», etc. Tan desvergonzada tergiversación constituye, según expresión del Santo Padre, un robo hecho al Sugrario y a la Religión. para perturbar y llenar de confusión las conciencias de los fieles). ${ }^{79}$

Analicemos finalmente la interrelación de tres materias que atrajeron la atención del mundo católico nacional en la década de 1930, acentuándose su discusión en el último lustro del decenio al calor de los acontecimientos españoles y su repercusión en la política chilena. $1 .^{\circ} \mathrm{La}$ doble lectura del conflicto español: de noticia internacional e interpretación como lección política; $2 .^{\circ}$ la situación de coyuntura de la política nacional ante la plataforma del Frente Popular y 3." la discusión del sistema corporativo, tanto como realidad desde los regímenes fascistas europeos como de proyecto político viable en el país.

El primer punto lo asumió «El Debate» desde el principio de

79 Carta de los Obispos Chilenos al Episcopado Alemán. A los Eminentísimos Sres. Cardenales, los Excmos. y Revmos. señores Arzobispos y Obispos de Alemania. «R. C.», noviembre de 1937, núm. 839, págs. 398-401. Los subrayados son míos. 
la guerra civil española. Los sucesos constituían una lección que había que meditar y difundir entre los católicos y sus adversarios: el meollo era considerar la gravitación de la tradición católical en el país y el modo de conducirse con la Iglesia. Esta línea periodística quedó delineada en su editorial de 25 de julio de 1936:

"Tenía que suceder.

Se había extremado la violencia de parte de los que llegaron al poder, sin respetar personas, sentimientos, sus tradiciones artísticas () religiosas"). ${ }^{80}$

Concluida la guerra civil, el semanario evaluó el desenlace y la lección española, en abril de 1939:

"Nunca hemos ocultado nuestras simpatías por la causa de los nacionalistas. De un examen imparcial de los hechos que provo. caron el estallido revolucionario sacamos la convicción de que la Justicia y el Derecho se encontraban de parte de los nacionalistas...

Los republicanos no nos asustaron... Desconfiamos de ellos cuando se manifestaron incapaces de mantener el orden social, obligación primaria de todo gobierno.

Los elementos de orden aparecieron tímidos, desconcertados y en minoría. Los débiles tienen también reacciones violentas. Ciuando y a todo lo consideran perdido son capaces de emular y aun superar la audacia de sus adversarios.

El trágico ejemplo de Éspaña es una elocuente prueba de que el respeto recíproco es una necesidad social),. ${ }^{81}$

El diagnóstico de la realidad socio-económica y política que vivía Chile, ${ }^{82}$ condujo a un cuestionamiento del régimen democrá-

80 Lo de España, «El Debate», 25 de julio de 1936. Editorial.

81 En España hay paz. «El Debate», 22 de abril de 1939. Los subrayados son míos. Indiquemos en este lugar que el periódico normalmente constó de cuatro páginas. Con ocasión del triunfo de Franco sacó una edición especial -la más voluminosa de su historia periodística-- el día 22 de abril de 1939 que totalizó veinte páginas dedicadas exclusivamente a dar a conocer el pensamiento de José Antonio Primo de Rivera, la nueva organización del Estado, etc.

82 En el curso del año 1936 \&La Revista Católica» se refirió a la inexistencia de «salario mínimo» como del «salario familiar», la reducida proporción de propie tarios, a los «muchos oídos de mercader para todo lo que sea predicación de caridad 
tico existente, vía el ejemplo español. ${ }^{83}$ Para «El Debate», desde la aprobación de la Constitución de 1925, un triunfo del liberalismo político, se había asistido a un retroceso de la influencia de la Iglesia en la sociedad. ${ }^{84} \mathrm{La}$ ofensiva de la Iglesia se basará en la Acción Católica y en el acendrado espíritu mariano en el pueblo, cuya devoción a la Virgen del Carmen era incuestionable. ${ }^{85} \mathrm{La}$ elec-

y de justicia social». Cfr. La última quincena. La tragedia hispánica, «R. C.», 8 de agosto de 1936, núm. 814, pág. 142.

Fustigó los gastos superfluos en obras públicas: «Para gastar en grandes plazas de la capital, mientras hay falta de hospitales en la República; para dar perspectivas exageradas a La Moneda, cuando las muchedumbres de pobres ven subir a las nubes los artículos de primera necesidad y la gente de clase media se ve obligada a apretarse la barriga para disimular su indigencia». Cfr. La última quincena. Burocracia. Gastos superfluos, «R. C.», 28 de noviembre de 1936, núm. 821, 554. Este panorama social y económico constituía una amenaza al orden social. Preguntándose « ¿Y por qué nos van a amenazar?», la misma revista católica se contestaba: «Pues por muchas razones: porque no se ha mejorado la condición de los pobres ni en su vivienda ni en su sustento; porque no hemos conquistado a esos obreros con asociaciones y sindicatos católicos, como lo han mandado los últimos Pontífices; porque ha habido muchos que se han abstenido, para avivir tranquilosi; fórmula del egoísmo. Y porque además de la intensa propaganda soviética nosotros mismos estamos provocando el odio del pueblo con insensatas manifestaciones de riqueza y de lujo». Cfr. La última quincena. Insensatez, $\ll$ R. C.», 8 de agosto de 1936, núm. 814, pág. $14 \%$.

83 «Como en España, estamos también nosotros amenazados de comunismo... Pero hay gentes que no creen en este peligro en Chile... Creen en las mágicas palabras de derecho, democracia, libertad: a ningún asesino vamos a desarmar con estas palabras cuando mañana nos ponga el arma homicida contra el pecho». Cfr. La última quincena. Insensatez, $\ll$ K. C.», \& de abril de 1936, núm. 814, pág. 142.

Más directo fue Manuel Rivas Fernández: «El gobierno totalitario de Franco... ha vinculado a España al block de naciones que han eliminado al dios de barro de la «Democracia». Cfr. A España en su tercer año triunfal, «El Debate», 16 de julio de 1938. Los subrayados de ambas citas son míos.

84 La situación político-jurídico-educacional de la nación, a partir de 1925, se sintetizaba para «El Debate en: «l." La separación de la Iglesia y el Estado; 2.0 La supresión del Presupuesto del Culto; 3." La eliminación casi absoluta de la Clase de Religión en los programas oflciales; 4." El Ateísmo práctico en una nación que todo lo debe a la Fe». Cfr. Explicación necesaria, «El Debate», 1 de octubre de 1932.

85 Es interesante apreciar cómo se formula desde «La Revista Católica» la celebración de la festividad de la Virgen del Carmen que, por Rescripto Apostólico del Papa Pío XI, de 24 de octubre de 1923, era declarada la Virgen del Monte Carmelo «Patrona principal de toda la República chilena».

Las procesiones públicas del mes de julio de 1936 son interpretadas por el órgano eclesial: «Se ve que el pueblo presiente la necesidad de recurrir al amparo protector de su Reina y Soberana ante las sombras amenazantes que muestran los horizontes del mundo y del país (CPr. La última quincena. Fiesta de Nuestra Sefiora del Carmen. «R. C.», 25 de julio de 1936, núm. 813, pág. 94).

En septiembre de 1936 se clausura el primer Congreso Nacional de Mujeres Católicas de Chile. Y ese mismo mes, en el homenaje tradicional a la Virgen, se 
ción de 1938 dividió sensiblemente a la nación, pues las plataformas políticas eran extremadamente antagónicas: la derecha política (donde el partido Conservador, el "partido católico» por excelencia, iba junto con el partido Liberal) y el Frente Popular (integrado por los partidos Radical, Socialista, Comunista, como fuerzas principales). Para algunos católicos, el triunfo del Frente Popular se iniciaría - como afirmaba Carlos Fernández Freite, capellán de la Penitenciaría de Santiago- «incendiando iglesias y asesinando sacerdotes»; ${ }^{86} \mathrm{o}$ bien se canalizaría como en Francia «a huelgas y uno que otro desmán en las fábricas, pero no se han incendiado iglesias ni se han cometido asesinatos con los sacerdotes ni religiosas». ${ }^{87}$ Pero, también la elección de 1938 marcó el fin de la visión monolítica del catolicismo político. En efecto, las discrepancias de la juventud conservadora —que tomaba el nombre de Falange Nacional - con el Partido Conservador, llevó a abandonar ese partido a los jóvenes -o sea la Falange Nacional- conducidos por Eduardo Frei, Radomiro Tomic, Manuel A. Garretón, Bernardo Leighton y otros, decretándose la libertad del voto. El triunfo estrecho de Pedro Aguirre Cerda, candidato del Frente Popular, abrió más la brecha entre ambos sectores católicos - los conser-

veriflca uno de los homenajes más grandes. La información resalta lo militar-religioso y también la presencia del catolicismo español e italiano: «Como esta procesión que lucía escolta de obispos de toda la República y guardia de cadetes de toda la Escuela Militar en uniforme de gala; viejos tercios de veteranos del 79; mujeres de la Acción Católica de toda la nación y simpáticas brigadas de mujeres espańolas con sus clásicas mantillas y mujeres italianas con su bandera y su estandarte de cofradía. Los hombres demostraron su fe: gruesas columnas de la Acción Popular marchaban con su estandarte patrí́tico y hasta grupos de nacistas saludaban a su manera al paso de la Reina de la Patriax. (Cfr. La última quincena. El homenaje tradicional a Nuestra Señora del Carmen, \&R. C.», 24 de octubre de 1936, número 819, pás. 434).

En octubre de 1937 el arzobispo de Santiago, estimando que la solución a todos los males de la sociedad pasaba por la regeneración de las personas y hogares, convocaba a cuna nueva Cruzada, amados Diocesanos, cruzada que podríamos llamar de salvación nacional, es la que deseamos iniciars. Cfr. Arzobispado. Circular. Acerca de la devoción a la Santísima Viroen del Carmen y la consagración de los Hogares, «R. C.», 20 de octubre de 1937, núm. 837, págs. 291-292.

86 Cfr. Carabinero ajusticiado, «R. C.», 24 de octubre de 1936, núm. 819, 423. Art. flrmado por Carlos Fernández Freite, capellán de la Penitenciaría de Santiago.

87 Cir. La última quincena. La tragedia hispánica. \&R. C.», 8 de agosto de 1936, núm. 814, pág. 141. Se hacía constar que aquello se debía fundamentalmente al trabajo del clero francés sen la cuestión social, ha estudiado el problema y se ha puesto a resolverlo con energía y constancia, por eso los obreros lo respetan». 
vadores y los falangistas- que convivían en el interior de la Acción Católica Chilena.

El triunfo de la izquierda fue encarado por «La Revista Católica», con ecuanimidad y sentido político:

"Asume las delicadas funciones el nuevo mandatario en circuns. tancias excepcionalmente difíciles para la República dividida en dos bandos políticos que propugnan la realización de programas antagónicos. Corresponde al nuevo Presidente de la República suavizar con rectitud y ecuanimidad las asperezas que dejó la reciente lucha electoral, convirtiéndose en el Presidente de todos los chilenos para trabajar por la grandeza y la prosperidad de nuestra nación. Anhelamos que el Primer Mandatario sepa conciliar las aspiraciones que sean justas de sus partidarios, con la paz social de todos los chilenos, de manera que satisfaga todos los derechos y por consiguiente que no desconozca los de aquellos que por dis. tintos caminos justos y honrados, desean cooperar a la grandeza y prosperidad de Chile, aportando un positivo mejoramiento económico y espiritual a las clases desvalidas, sin menoscabo de los eternos principios de la verdadera justicia)., ${ }^{88}$

Resta decir que el Frente Popular chileno fue el de más prolongada existencia.

La nueva realidad política que emergió en Chile en 1938 en cierta medida clausuró el intenso debate del catolicismo en torno al corporativismo como modelo político, no faltando ciertamente los que asintieron la identificación plena entre el corporativismo y los regímenes fascistas entonces imperantes en Europa.

88 El Nuevo Presidente de Chile Excmo. Sr. Don Pedro Aguirre Cerda. «R. C.», diciembre de 1938, núm. 852, pág. 671. Por su parte «El Debate», recordando que sla guerra civil en la Madre Patria es una torpeza debida a las violencias de la República, especialmente en el orden religioso» y en Francia sólo se ha edesorganizado la economía reconocía shidalgamente que, salvo declaraciones esporádicas, el Frente Popular chileno ha sabido apartar de la lucha el factor religioso con lo que se asemeja al proceder de los Frentistas Pranceses... Saludamos al Presidente Electo de la República». Cfr. El triunfo del Frente Popular, \&El Debate»,29 de octubre de 1938. Edit. 
En el mundo católico chileno - siguiendo los reflejos de las discusiones y realizaciones en la esfera ibera-latina, v. gr. Italia, Portugal, España - se vivió intelectualmente la búsqueda de «un contexto de pensamiento y de acción mezclando las consideraciones tradicionalistas por el orden y la jerarquía con el nuevo imperativo de cambio y modernización». ${ }^{89} \mathrm{Y}$ en tal debate las corrientes renovadoras de la Iglesia también jugaban su papel.

La ventilación del corporativismo - como preocupación intelectual a partir de las orientaciones de las encíclicas papales, como desde el acercamiento a la praxis de los regímenes fascistas italiano y portugués- estuvo unida a la realización de un programa social cristiano, inspirado en la organización gremial y corporativa de la sociedad. Para los jóvenes universitarios católicos - la élite de la juventud conservadora - había que reponer urgentemente, como pedía Bernardo Leighton, el «concepto cristiano del bien común». 90 Para Manuel A. Garretón se podía hacer convergente el ideal corporativista con el sentimiento de patria y unidad nacional. ${ }^{91}$ Otros, como Jaime Eyzaguirre, Julio Philippi, dieron cuenta de los avances de las experiencias corporativistas europeas, viendo en ellas elementos a emular. ${ }^{92}$ En tal sentido la revista «Estudios» fue un lugar donde se fraguó seriamente un proyecto autoritario corporativista. ${ }^{93}$ Los ejemplos de Austria - con Dollfus-e Italia fueron examinados con prolijidad. Pedro Lira Urquieta vio como obstáculo el «exagerado estatismo que predomina, a lo menos temporalmente,

89 Wiarda, Howard J.: Hacia un Sistema Teórico para el Estudio del Proceso de Cambio Socio-politico dentro de la Tradición Ibero-Latina: El Modelo Corporativo, «Estudios Andinos», año 4, vol. IV, núm. 1, 1974-1975, pág. 249.

90 Leighton Guzmán. Bernardo: «a obra de la Universidad Católica. «Revista Universitaria», julio 1934, núm. 4, págs. 371-395.

91 Garretón, Manuel A.: Hacia un ideal político, «Revista Universitaria», noviembre-diciembre 1934, núms. 8-9, págs. 863-882.

92 Vid. Jaime Eyzaguirre: Los avances del corporativismo, «Estudios», número 14, 1934, pág. 34. Julio Philippi: Politica, partido politico y corporativismov «Estudios», núm. 21, 1934.

93 Vid. J. J. Brunner y Gonzalo Catalán: Cinco Estudios sobre Cultura y Sociedad. Santiago. Estudio 3: Notas sobre Proyectos Autoritarios Corporativos en Chile: la Revista Estudios 1933-1938. 
en las leyes fascistas». ${ }^{94}$ Alfredo Bowen rechazó el modelo fascista italiano pero ensayó una propuesta corporativista que abarcó lo político, lo educacional, lo internacional. Como afirma Fernando Aliaga, «es preciso reconocer que si bien se plantea un rechazo al fascismo italiano como hecho y cultura, no obstante se advierte una cierta admiración por sus logros». ${ }^{95} \mathrm{Y}$ fue debido - como reconociera Eduardo Frei en 1933 - a que el corporativismo abarcó una inmensidad de conceptos, que hubo necesariamente la separación entre los que, como él, plantearon una concepción de la sociedad donde la personalidad y la dignidad del hombre fuese lo fundamental, y a ella estuviesen sujetas la sociedad y el Estado, siguiendo las orientaciones de Jacques Maritain; ${ }^{96}$ y los que abrazaron el corporativismo, en su modelo fascista, haciendo predominar el Estado sobre el individuo. $\mathrm{Y}$ en tal perspectiva, la experiencia de la guerra civil española abrió con el triunfo de Franco en 1939 otro modelo corporativista, antidemocrático, pero distintivo de los modelos italiano y alemán, por la vinculación de los intereses políticoreligiosos, por la fusión del Estado-Iglesia, donde el hispanismo encontró amplio terreno de propagación ideológica.

Exponente de la corriente corporativa de corte fascista fue Manuel Fernández Rivas. El triunfo de Franco significaba ya en 1938:

94 Lira Urquieta, Pedro: Austria y su nueva Constitución, \&Revista Universitaria», julio 1934, núm. 4, págs. 485-504. También El Estado Cristiano en Austria, «El Debatex, 20 de enero de 1934.

95 Aliaga, Fernando: Fundadores de la Acción Católica chilena..., pág. 25. Para «La Revista Católica» la Acción Católica italiana era el amodelo en el mundo católico». (Cfr. «R. C.», 24 de julio de 1937, núm. 833, pág. 46), y se eloglaba la acción del imperialismo italiano en Etiopía. (Cfr. $\&$ R. C.», 8 de agosto de 1936 , núm. 814. pág. 139). «El Debate» celebraba la prohibición de la masonería en la Italia de Mussolini. (Cfr. Fascismo y masonería, «El Debate», 17 de febrero de 1934). En febrero de 1938 se reflrió a A. de Oliveira Salazar, restaurador de Portugal. Cfr. «El Debate», 12 de febrero de 1938.

96 Aliaga, Fernando: Fundadores de la Acción Católica chilena.... pág. 24. El proyecto político de la Falange Nacional, al considerar los valores de la idea de libertad individual y de justicia social se alejó de la solución fascista, a kpesar de su aversión a la democracia liberal». Cfr. Sol Serrano: Del conservantismo a la modernización: la visión histórica de la Falange Nacional en Chile, «Alternativas», junio 1984, número especial, pág. 167. 
"La revolución que dirige el Generalísimo Franco es la reacción de España contra la anti España.

Es la dignificación del Estado sin menoscabo de la individualidad humana.

Es la continuación de la lucha contra el comunismo iniciado con éxito por Hitler, Mussolini y Oliveira Salazar.

Es la extinción de la masonería en la tierra de los Reyes Católicos...

Es la formación del Corporativismo como régimen de trabajo.

El gobierno totalitario de Franco no tendrá colisiones con el catolicismo.

El totalitarismo español del presente se basa en la tradición nacional.

Y la tradición española es eminentemente católica. Será la tradición española en moldes nuevos». ${ }^{97}$

El distanciamiento por la Falange Nacional del modelo corporativista en sus expresiones fascistas, su actitud ante las elecciones de 1938, lo condujo a romper la unidad de criterio del catolicismo chileno ante el carácter de cruzada de la guerra civil española con su ulterior cuestionamiento del régimen franquista. En esa postura influyó la posición de Jacques Maritain ante el conflicto español. ${ }^{98}$

Señalemos finalmente que la Falange Nacional discrepará fuertemente con la jerarquía eclesiástica chilena, en 1947, entre otras cosas, por su manifestación de «un criterio disonante a la jerarquía, no sólo la de Chile, sino la del Papa y de todo el Episcopado del

97 A España en su tercer año triunfal, $\&$ El Debate», 16 de julio de 1938.

98 Maritaín habla expresado en el prólogo a Alíredo Mendizábal, Aux origines d'une tragedie. La politique espagnole de 1923 d 1936: aNo pensamos faltar en nada al respeto debido a esa Carta (Colectiva de los obispos españoles) ni a las reglas generales de la conducta católica, no siguiendo el documento episcopal en la opción sin reservas que él expresa en favor del campo nacional». Citado por Rafael Calvo Serer, La literatura universal sobre la ouerra de Espafia, Madrid, 1962. pás. 45.

Fernández Rivas atacó con dureza a Maritain desde las pácinas de «El Debaten. CPr. Jacques Maritain, «El Debate», 24 de diciembre de 1938. 
mundo, que piensa como $\mathrm{El}$ ỳ con $\mathrm{El}$ (ante) la cuestión española». ${ }^{49}$ Fue la mayor crisis política de la Falange Nacional con la Iglesia. $\mathrm{Y}$ el último eco de la guerra civil española en el catolicismo chileno. ${ }^{100}$

\section{CONCLUSIONES}

La guerra civil española produjo un enorme impacto en la vida nacional chilena. No hubo parcela de la sociedad que no se pronunciara sobre lo que acontecía en la península ibérica: los intelectuales, los partidos políticos, las instituciones y la Iglesia. Como hemos expuesto, el conflicto fue asumido siguiendo las pautas adoptadas en suelo español por la propia Iglesia. Conjuntamente con la evolución de la guerra fratricida se desplegaron entre las publicaciones católicas interesantes debates alrededor del hispanismo, el revisionismo historiográfico y al modelo corporativista.

99 El Cardenal Arzobispo de Santiago orienta a los católicos en la crisis politica que ha sufrido la Falange Nacional, «El Debate», 26 de diciembre de 1947. Aquello a su vez significó el cierre del periódico.

Sobre las relaciones entre el Vaticano y el gobierno de Franco, remito a Vicente Cárcel Ortí: La Iglesia en la segunda República..., págs. 382 y ss.

S. S. Pío XI ya, en su discurso de 4 de septiembre de 1936 en Castelgandolfo, se habla pronunciado por los que luchaban por adefender y restaurar los derechos y el honor de Dios y de la Religión», hasta fljar la posición de la Santa Sede ante el nuevo gobierno español de Franco, en su Mensaje de 16 de abril de 1939.

100 La iglesia chilena debió, en 1946, editar un folleto referido a las condenas eclesiales a los regimenes de Hitler y de Mussolini, ante los ataques de la prensa de izquierda ( $\ll$ La Nación», «La Hora» y «El Siglo») sobre las relaciones entre la Iglesia y los regímenes totalitarios, entre los cuales al de Franco habla mostrado simpatía eaunque es de tinte fascista». En esa oportunidad reprodujo los párrafos más elocuentes de los lextos pontiflcios indicados en la nota precedentè. además de la Pastoral Colectiva de los Obispos españoles y la enciclica .Dilectissima Nobis», de 3 de junio de 1933 . En la presentación de los textos afirmaba la iglesia chilena que fue legítima la defensa contra la anarquía y la criminal persecución: \&Esto lo ha alabado el Vaticano, porque fue salvador para la Iglesia y es honra de quienes lo realizaron. De aquí no se deduce que la guerra de España fuera santa, ni nunca lo ha aflrmado la Santa Sedex. Sobre los caracteres del gobierno franquista, indicaba que para la Iglesia sle basta que el gobierno sea legitimo. De esto último no cabe duda, así por lo establecido por el derecho natural, como por el reconocimiento de los demás estados».

Cfr. Acción Católica Chilena, La Iglesia y el Fascismo. Secretariado Nacional de Prensa. Sántiago, 1946, pág. 6 (citas) y el apartado La Iolesia y los cambios políticos de España (págs. 22-29), selección de los textos ya mencionados. 
Mientras algunos temas se mantuvieron vigentes más allá del término del conflicto, como la escuela historiográfica hispanista, otros quedaron silenciados, como el corporativismo, al ser rechazado en sus interpretaciones autoritaria fascista y asociarse al destino histórico de los regímenes totalitarios durante la segunda guerra mundial.

Coadyuvó a la repercusión de la guerra civil española en Chile, la configuración de una realidad política próxima a ella, en su forma, mas no en el fondo, como fue la gestación del Frente Popular y su ulterior triunfo en 1938. Asimismo, no puede minimizarse dicho impacto en el catolicismo chileno, en momentos en que éste se hallaba en pleno renacimiento intelectual ni su presencia activa en la sociedad a través de la Acción Católica. Las fuentes ideológicas del bando nacionalista así como la experiencia religiosa - de la persecución y la hegemonía que alcanza en el campo franquistarepercutieron con fuerza en las publicaciones católicas.

La guerra civil española constituyó, por el debate abierto en sus vertientes culturales, políticas, religiosas, el acontecimiento extranjero más influyente en la vida católica chilena de la primera mitad del siglo XX.

José Antonio González Pizarro 